\title{
PENGARUH PEMBERIAN MICRONUTRIENT SPRINKLE TERHADAP STATUS ANTROPOMETRI BB/U, TB/U DAN BB/TB ANAK STUNTING USIA 12-36 BULAN
}

\author{
Nadia Hapsari Oktarina, Martha Irene Kartasurya ${ }^{*}$ \\ Program Studi Ilmu Gizi Fakultas Kedokteran Universitas Diponegoro \\ Jl.Dr.Sutomo No.14, Semarang, Telp (024) 8453708, Email : gizifk@undip.ac.id
}

\begin{abstract}
Background : Micronutrient inadequacy is one of child nutritional problems in Indonesia, therefore micronutrient supplementation can be used to improve child nutritional status. In developing countries, micronutrient sprinkle has been used for supplementation program. This study aimed to analyze the effect of micronutrient sprinkle supplementation on WAZ, HAZ and WHZ scores of stunting children aged 12-36 months.

Methods : Experimental design with pre post test and control group was used in this study. The study population was children aged 12-36 months in Rowosari village, Tembalang, Semarang. Fifty subjects from posyandu were divided randomly into treatment and control groups. The treatment group received 30 sachets of micronutrient sprinkle for 60 days. Both groups received nutrition education every 2 weeks. Nutrient intake was measured by $3 \times 24$ hour recall. Weight and height were measured at baseline, one and two months after intervention started. Data were analyzed by Anova and independent t-tests.

Results : Nine subjects were dropped out of this study due to their low compliance and moving. The mean body weight of the treatment group increased from $9.3 \pm 1.3 \mathrm{~kg}$ to $9.8 \pm 1.2 \mathrm{~kg}$ after 2 months, while in the control group change from $9.3 \pm 1.5 \mathrm{~kg}$ to $9.4 \pm 1.4 \mathrm{~kg}$. The mean height of the treatment group increased from $76.2 \pm 6.2 \mathrm{~cm}$ to $79.3 \pm 5.5 \mathrm{~cm}$, while in the control group increased from $76.5 \pm 5.9 \mathrm{~cm}$ to $78.4 \pm 5.8 \mathrm{~cm}$. The mean increase in height in treatment group were higher than the control group. HAZ scores in the treatment group increased from $3.1 \pm 0.7$ to $-2.5 \pm 0.6$, while in the control group increased from $-3.0 \pm 0.8$ to $-2.9 \pm 0.9$. The mean HAZ score increase in the treatment group were higher than the control group.

Conclusions : Micronutrient sprinkle supplementation for 2 months increased HAZ scores of stunting children aged 12-36 months.
\end{abstract}

Keywords : micronutrient sprinkle; stunting children aged 12-36 months

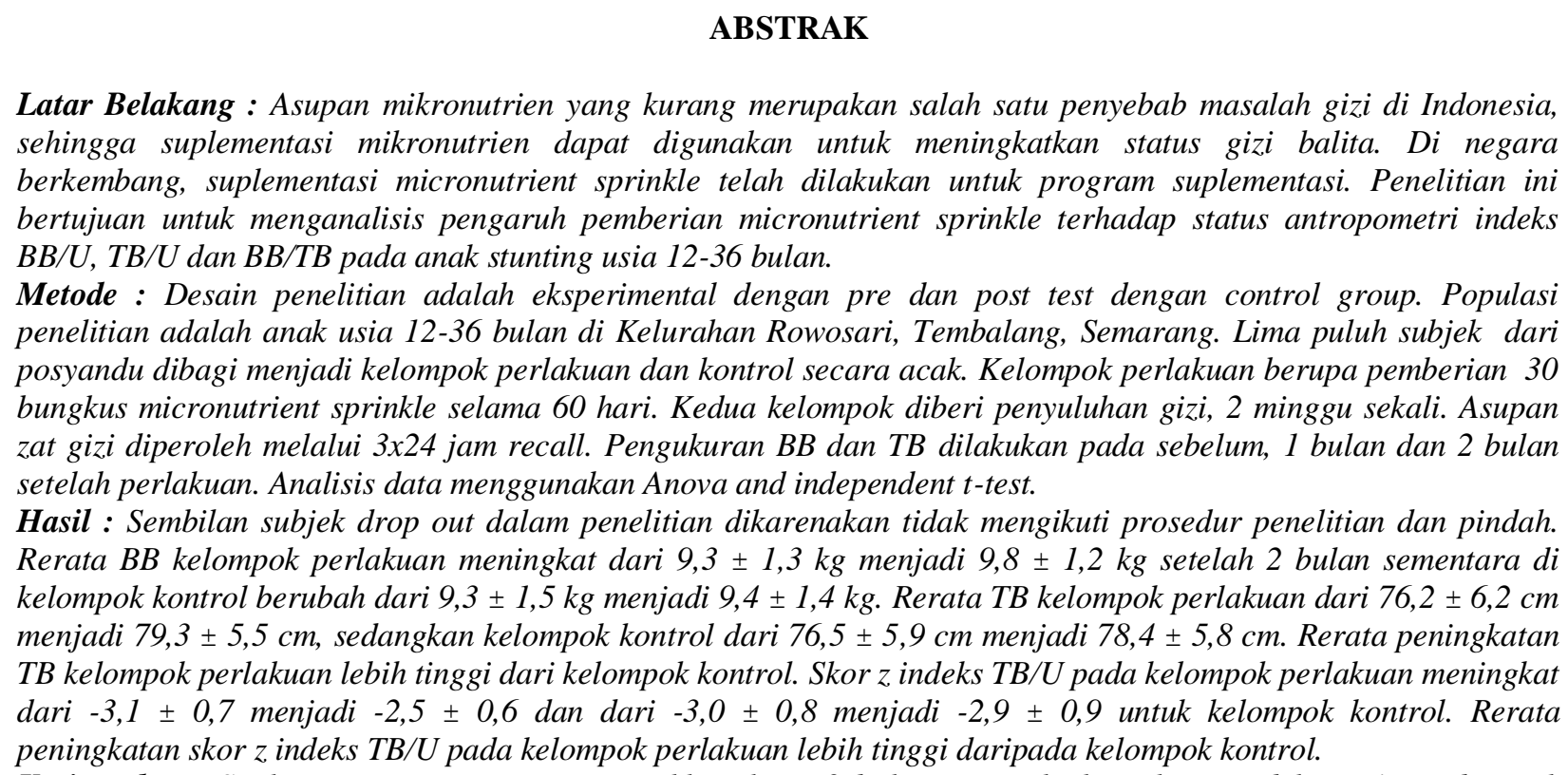
Kesimpulan : Suplementasi micronutrient sprinkle selama 2 bulan meningkatkan skor $z$ indeks TB/U pada anak stunting usia 12-36 bulan.

Kata kunci : micronutrient sprinkle; anak stunting usia 12-36 bulan 


\section{PENDAHULUAN}

Stunting merupakan kondisi kronis yang menggambarkan grafik pertumbuhan yang terhambat terjadi selama periode sebelum dan sesudah kehamilan karena kekurangan zat gizi dalam jangka panjang. ${ }^{1}$ Sekitar $43 \%$ anak-anak di seluruh dunia menderita stunting. Prevalensi stunting di Indonesia berdasarkan Nutrition and Heath Surveillance Survey (NSS) tahun 2001 yaitu 46,6\%. ${ }^{2}$ Jawa Tengah (2010) memiliki prevalensi balita pendek $17 \%$ dan prevalensi untuk balita sangat pendek $16,9 \%{ }^{3}$ Kota Semarang (2011) memiliki prevalensi anak pendek 13,57\% dan anak sangat pendek $7,09 \%$ sedangkan prevalensi anak stunting di kecamatan Tembalang untuk anak pendek 20,08\% dan sangat pendek 20,08\%.

Faktor penyebab stunting terdiri dari faktor langsung dan tidak langsung. Faktor langsung disebabkan karena defisiensi makronutrien serta mikronutrien dan penyakit infeksi yang sering terjadi pada balita, seperti ISPA dan diare. Faktor tidak langsung seperti pendidikan, demografis, ketersediaan pangan dan pelayanan kesehatan. ${ }^{4}$ Kekurangan asupan zat gizi individu merupakan salah satu penyebab masalah zat gizi dan menyebabkan terjadinya gangguan pertumbuhan pada anak. Defisiensi zat gizi makro memberi dampak terhadap penurunan status gizi dalam kurun waktu yang singkat tetapi defisiensi zat gizi mikro (vitamin dan mineral) memberi dampak terhadap penurunan status gizi dalam kurun waktu yang lebih lama.,

Studi efikasi menunjukkan bahwa micronutrient sprinkle mampu menurunkan anemia secara bermakna. ${ }^{7,8}$ Penelitian di Skotlandia menunjukkan bahwa suplementasi micronutrient sprinkle selama 3 minggu meningkatkan indeks skor z indeks TB/U sebesar 1 SD pada anak usia 659 bulan dan mencapai tumbuh kejar sepenuhnya sekitar 2 bulan. ${ }^{9}$ Penelitian di Pangkep menunjukkan bahwa pemberian micronutrient sprinkle dengan dosis satu kali sehari selama 4 bulan meningkatkan status gizi 6 balita $(20,7 \%)$ dari 29 balita gizi kurang. ${ }^{10}$

Kecamatan Tembalang merupakan daerah terpilih untuk penelitian micronutrient sprinkle karena tingginya prevalensi anak stunting di wilayah tersebut. Subjek penelitian adalah balita berusia 12-36 bulan karena prevalensi stunting paling banyak pada usia balita dan pada usia 12 bulan sudah bisa diberi makanan pendamping ASI (MP ASI).

\section{METODE PENELITIAN}

Desain penelitian yang digunakan adalah true experiment dengan rancangan pre dan post test with control group. Penelitian dilakukan pada bulan Juli-Agustus 2012 di Kelurahan Rowosari, Kecamatan Tembalang Semarang.

Jumlah subjek yang diambil berdasarkan rumus beda rerata 2 populasi:

$$
\begin{aligned}
& \mathrm{n}_{1}=\mathrm{n}_{2}=2\left[\frac{1,64 \times 0,33}{0,17}\right]^{2} \\
& \mathrm{n}_{1}=\mathrm{n}_{2}=20 \\
& \text { drop out } 25 \%=25
\end{aligned}
$$

Anak usia 12-36 bulan yang menderita stunting di posyandu Kelurahan Rowosari diikutsertakan dalam penelitian ini. Selanjutnya, 50 subjek dibagi menjadi kelompok perlakuan dan kontrol secara acak, di akhir penelitian hanya terdapat 20 subjek kelompok perlakuan dan 21 subjek kelompok kontrol, tetapi jumlah tersebut telah memenuhi sampel minimal penelitian. Terdapat 8 subjek drop out dalam penelitian dikarenakan tidak mengikuti prosedur penelitian dan 1 subjek drop out karena subjek pindah tempat tinggal.

Variabel bebas dalam penelitian ini yaitu pemberian taburia. Taburia mengandung 16 vitamin dan mineral (vit A $417 \mathrm{mcg}$, vit B1 $0,5 \mathrm{mg}$, vit B2 $0,5 \mathrm{mg}$, vit B3 $0,5 \mathrm{mg}$, vit B6 5mg, vit B12 $1 \mathrm{mcg}$, vit D3 $5 \mathrm{mcg}$, vit E $6 \mathrm{mg}$, vit $\mathrm{K} 20 \mathrm{mcg}$, vit C $30 \mathrm{mg}$, asam folat $150 \mathrm{mcg}$, asam pantotenat $3 \mathrm{mg}$, yodium $50 \mathrm{mcg}$, zat besi $10 \mathrm{mg}$, seng $6 \mathrm{mg}$ dan selenium 20mcg). Dosis pemberiannya yaitu 2 hari sekali selama 2 bulan (dihitung manggunakan form daya terima). Variabel terikat adalah status antropometri berupa skor $\mathrm{z}$ indeks BB/U, TB/U dan BB/TB. TB subjek diukur menggunakan microtoise dengan ketelitian $0,1 \mathrm{~cm}$ sedangkan $\mathrm{BB}$ diukur menggunakan tumbangan digital dengan ketelitian $0,1 \mathrm{~kg}$. Variabel perancu adalah asupan makan balita (dihitung menggunakan form food recall). Food recall 3x24 jam dilakukan sebelum, pada saat dan setelah perlakuan. Data penyakit diare dan ISPA diperoleh melalui wawancara menggunakan formulir morbiditas. Kelompok perlakuan dan kontrol diberikan edukasi gizi setiap 2 minggu sekali selama penelitan.

Normalitas diuji menggunakan SaphiroWilk. Perbedaan skor $\mathrm{z}$ indeks sebelum, 1 bulan dan 2 bulan setelah intervensi pada masing-masing kelompok diuji dengan Anova. Perbedaan skor z indeks antara kedua kelompok diuji dengan independent t-test. Pengujian dilakukan dengan tingkat kepercayaan $95 \%$ dan dikatakan signifikan $p<0,05$. 
HASIL PENELITIAN

Karakterisitik subjek penelitian pada kedua kelompok disajikan pada Tabel 1.

Tabel 1. Karakteristik Subjek Penelitian

\begin{tabular}{|c|c|c|c|c|c|}
\hline \multirow{2}{*}{ Variabel } & \multirow{2}{*}{\multicolumn{2}{|c|}{$\begin{array}{c}\text { Perlakuan }(n=20) \\
\text { Mean } \pm \text { SD }\end{array}$}} & \multicolumn{2}{|c|}{ Kontrol $(n=21)$} & \multirow[b]{2}{*}{$p$} \\
\hline & & & & & \\
\hline Usia (bulan) & \multicolumn{2}{|c|}{$23,4 \pm 8,7$} & \multicolumn{2}{|c|}{$24,5 \pm 6,5$} & $0,38^{\mathrm{s}}$ \\
\hline TKE sebelum & \multicolumn{2}{|c|}{$96,1 \pm 21,9$} & \multicolumn{2}{|c|}{$98,6 \pm 32,7$} & $\overline{0,776^{1}}$ \\
\hline TKP sebelum & \multicolumn{2}{|c|}{$111,8 \pm 37,8$} & \multicolumn{2}{|c|}{$110,6 \pm 46,6$} & $0,929^{1}$ \\
\hline \multirow[b]{2}{*}{ Jenis Kelamin } & $\mathrm{n}$ & $\%$ & $\mathrm{n}$ & $\%$ & $p$ \\
\hline & 13 & 65 & 8 & 38,1 & $0,885^{\mathrm{s}}$ \\
\hline
\end{tabular}

Keterangan: $s=$ uji Chi-square, $i=$ independent $t$-test

Rerata usia subjek pada kelompok perlakuan 23,4 bulan dan tidak berbeda dengan kelompok kontrol 24,5 bulan. Tidak adanya perbedaan tingkat kecukupan energi dan protein pada kelompok perlakuan dan kontrol sebelum dilakukan penelitian. Tidak ada perbedaan jenis kelamin antara kedua kelompok.

Status Antropometri Sebelum dan Setelah Intervensi

BB dan TB subjek pada kelompok perlakuan dan kontrol mengalami peningkatan setelah 1 dan 2 bulan perlakuan tetapi peningkatan ini tidak signifikan secara statistik $(p>0,05)$. Pada kelompok perlakuan, ada perbedaan skor $\mathrm{z}$ indeks
TB/U antara sebelum, 1 bulan dan 2 bulan setelah perlakuan $(p=0,03)$ dari $-3,1 \pm 0,7$ menjadi $-2,5 \pm$ 0,6 selanjutnya uji Post Hoc dengan LSD menunjukkan bahwa antara sebelum dan 2 bulan ada perbedaan signifikan dengan skor $\mathrm{z}$ indeks $\mathrm{TB} / \mathrm{U} \quad(p=0,010)$, sedangkan pada kelompok kontrol tidak ada perbedaan yang signifikan. Tidak ada perbedaan skor $\mathrm{z}$ indeks $\mathrm{BB} / \mathrm{U}$ dan $\mathrm{BB} / \mathrm{TB}$ kelompok perlakuan maupun kelompok kontrol. Uji perbedaan $\mathrm{BB}, \mathrm{TB}$, skor $\mathrm{z}$ indeks $\mathrm{BB} / \mathrm{U}, \mathrm{TB} / \mathrm{U}$ dan $\mathrm{BB} / \mathrm{TB}$ sebelum dan setelah intervensi pada kedua kelompok dilakukan untuk mengetahui ada tidaknya pengaruh intervensi dapat dilihat pada Tabel 2.

Tabel 2. Status Antropometri Sebelum dan Setelah Intervensi

\begin{tabular}{|c|c|c|c|c|}
\hline \multirow[t]{2}{*}{ Variabel } & \multicolumn{2}{|c|}{ Perlakuan $(n=20)$} & \multicolumn{2}{|c|}{ Kontrol $(n=21)$} \\
\hline & Mean \pm SD & $p$ & Mean \pm SD & $p$ \\
\hline \multicolumn{5}{|l|}{ BB $(\mathrm{kg})$} \\
\hline Sebelum & $9,3 \pm 1,1$ & \multirow{3}{*}{$0,352^{\mathrm{A}}$} & $9,3 \pm 1,5$ & \multirow{3}{*}{$0,901^{\mathrm{A}}$} \\
\hline 1 bulan & $9,6 \pm 1,2$ & & $9,4 \pm 1,3$ & \\
\hline 2 bulan & $9,8 \pm 1,2$ & & $9,4 \pm 1,4$ & \\
\hline \multicolumn{5}{|l|}{ TB $(\mathrm{cm})$} \\
\hline Sebelum & $76,2 \pm 6,2$ & \multirow{3}{*}{$0,259^{\mathrm{A}}$} & $76,5 \pm 5,9$ & \multirow{3}{*}{$0,554^{\mathrm{A}}$} \\
\hline 1 bulan & $78,6 \pm 5,7$ & & $77,9 \pm 5,8$ & \\
\hline 2 bulan & $79,3 \pm 5,5$ & & $78,4 \pm 5,8$ & \\
\hline \multicolumn{5}{|l|}{ Skor z BB/U } \\
\hline Sebelum & $-1,9 \pm 0,9$ & \multirow{3}{*}{$0,806^{\mathrm{K}}$} & $-2,1 \pm 1,3$ & \multirow{3}{*}{$0,899^{\mathrm{A}}$} \\
\hline 1 bulan & $-1,8 \pm 0,5$ & & $-2,0 \pm 1,2$ & \\
\hline 2 bulan & $-1,8 \pm 0,8$ & & $-2,2 \pm 1,1$ & \\
\hline \multicolumn{5}{|l|}{ Skor z TB/U } \\
\hline Sebelum & $-3,1 \pm 0,7$ & \multirow{3}{*}{$0,030^{\mathrm{A}}$} & $-3,0 \pm 0,8$ & \multirow{3}{*}{$0,693^{\mathrm{A}}$} \\
\hline 1 bulan & $-2,7 \pm 0,7$ & & $-2,8 \pm 0,9$ & \\
\hline 2 bulan & $-2,5 \pm 0,6$ & & $-2,9 \pm 0,9$ & \\
\hline \multicolumn{5}{|l|}{ Skor z BB/TB } \\
\hline Sebelum & $-0,1 \pm 1,3$ & \multirow{3}{*}{$0,565^{\mathrm{K}}$} & $-0,7 \pm 1,7$ & \multirow{3}{*}{$0,903^{\mathrm{A}}$} \\
\hline 1 bulan & $-0,6 \pm 0,9$ & & $-0,8 \pm 1,7$ & \\
\hline 2 bulan & $-0,7 \pm 1,0$ & & $-0,9 \pm 1,5$ & \\
\hline
\end{tabular}

Keterangan: $A=$ ANOVA, $K=$ Kruskal-Wallis 
Perubahan Status Antropometri Antara Kelompok Perlakuan dan Kontrol

Adanya peningkatan TB dan skor $\mathrm{z}$ indeks TB/U yang bermakna antara kelompok perlakuan dan kontrol setelah 1 bulan dan 2 bulan intervensi. Tidak ada perbedaan peningkatan skor $\mathrm{z}$ indeks $\mathrm{BB} / \mathrm{U}$ dan $\mathrm{BB} / \mathrm{TB}$ yang bermakna $(p>0,05)$. Perbedaan perubahan $\mathrm{BB}, \mathrm{TB}$, skor $\mathrm{z}$ indeks $\mathrm{BB} / \mathrm{U}$, $\mathrm{TB} / \mathrm{U}$ dan BB/TB antara kelompok perlakuan dan kontrol dapat dilihat pada Tabel 3.

Tingkat Kecukupan Energi dan Protein Sebelum dan Setelah Intervensi
Pada kelompok perlakuan, ada perbedaan tingkat kecukupan energi antara sebelum, 1 bulan dan 2 bulan $(p=0,024)$ selanjutnya uji Post Hoc dengan LSD menunjukkan bahwa ada perbedaan signifikan antara sebelum dan 1 bulan $(p=0,036)$ serta sebelum dan 2 bulan intervensi $(p=0,010)$, sedangkan pada kelompok kontrol tidak ada perbedaan. Tidak ada perbedaan tingkat kecukupan protein pada kelompok perlakuan maupun kontrol. Perbedaan tingkat kecukupan energi dan protein dapat dilihat pada Tabel 4.

Tabel 3. Perbedaan Skor Z Sebelum dan Setelah Intervensi Antara Kelompok Perlakuan dan Kontrol

\begin{tabular}{|c|c|c|c|}
\hline Variabel & $\begin{array}{c}\text { Perlakuan }(\mathrm{n}=20) \\
\text { Mean/Median } \pm \text { SD }\end{array}$ & $\begin{array}{c}\text { Kontrol }(\mathrm{n}=21) \\
\text { Mean/Median } \pm \\
\text { SD }\end{array}$ & $p$ \\
\hline $\begin{array}{c}\Delta \mathrm{BB}(\mathrm{kg}) \\
\text { sebelum - } 1 \text { bulan } \\
1-2 \text { bulan } \\
\text { sebelum - } 2 \text { bulan } \\
\end{array}$ & $\begin{array}{l}0,5 \pm 0,5 \\
0,2 \pm 0,2 \\
0,5 \pm 0,7 \\
\end{array}$ & $\begin{array}{c}0,1 \pm 0,9 \\
-0,1 \pm 0,8 \\
0,2 \pm 0,6 \\
\end{array}$ & $\begin{array}{c}0,290^{\mathrm{w}} \\
0,061^{\mathrm{w}} \\
0,76^{\mathrm{i}}\end{array}$ \\
\hline $\begin{array}{c}\Delta \mathrm{TB}(\mathrm{cm}) \\
\text { Sebelum - } 1 \text { bulan } \\
1-2 \text { bulan } \\
\text { sebelum }-2 \text { bulan }\end{array}$ & $\begin{array}{l}1,8 \pm 1,1 \\
1,3 \pm 0,7 \\
3,0 \pm 1,2\end{array}$ & $\begin{array}{l}1,4 \pm 1,1 \\
0,3 \pm 0,5 \\
1,9 \pm 1,2\end{array}$ & $\begin{array}{l}0,297^{\mathrm{i}} \\
0,000^{\mathrm{w}} \\
0,004^{\mathrm{i}}\end{array}$ \\
\hline $\begin{array}{c}\Delta \text { Skor } \mathrm{z} \text { indeks BB/U } \\
\text { Sebelum - } 1 \text { bulan } \\
1 \text { - } 2 \text { bulan } \\
\text { sebelum }-2 \text { bulan } \\
\end{array}$ & $\begin{array}{c}0,3 \pm 0,5 \\
-0,1 \pm 0,3 \\
0,1 \pm 0.5 \\
\end{array}$ & $\begin{array}{r}0,0 \pm 0,8 \\
-0,2 \pm 0,7 \\
-0,1 \pm 0,6 \\
\end{array}$ & $\begin{array}{r}0,246^{\mathrm{w}} \\
0,175^{\mathrm{w}} \\
0,171^{\mathrm{i}} \\
\end{array}$ \\
\hline $\begin{array}{c}\Delta \text { Skor } \mathrm{z} \text { indeks } \mathrm{TB} / \mathrm{U} \\
\text { Sebelum - } 1 \text { bulan } \\
1 \text { - } 2 \text { bulan } \\
\text { Sebelum }-2 \text { bulan }\end{array}$ & $\begin{array}{l}0,4 \pm 0,4 \\
0,2 \pm 0,2 \\
0,5 \pm 0,4\end{array}$ & $\begin{array}{c}0,2 \pm 0,4 \\
-0,1 \pm 0,2 \\
0,2 \pm 0,4\end{array}$ & $\begin{array}{l}0,190^{\mathrm{i}} \\
0,000^{\mathrm{w}} \\
0,003^{\mathrm{i}}\end{array}$ \\
\hline $\begin{array}{c}\Delta \text { Skor z indeks BB/TB } \\
\text { Sebelum - } 1 \text { bulan } \\
1 \text { - } 2 \text { bulan } \\
\text { sebelum - } 2 \text { bulan }\end{array}$ & $\begin{array}{c}0,0 \pm 0,8 \\
-0,1 \pm 0,6 \\
-0,3 \pm 0,9\end{array}$ & $\begin{array}{l}-0,1 \pm 1,2 \\
-0,2 \pm 1,0 \\
-0,3 \pm 0,8\end{array}$ & $\begin{array}{l}0,836^{\mathrm{i}} \\
0,557^{\mathrm{w}} \\
0.548^{\mathrm{w}}\end{array}$ \\
\hline
\end{tabular}

Keterangan: $i=$ independent $t$-test, $w=$ Mann-Whitney

Tabel 4.Tingkat Kecukupan Energi dan Protein Sebelum dan Setelah Intervensi

\begin{tabular}{ccccc}
\hline Variabel & \multicolumn{2}{c}{ Perlakuan $(\mathrm{n}=20)$} & \multicolumn{2}{c}{ Kontrol $(\mathrm{n}=21)$} \\
& Mean \pm SD & $p$ & Mean \pm SD & $p$ \\
\hline Tingkat Kecukupan & & & & \\
Energi & $96,1 \pm 21,9$ & & $98,6 \pm 32,7$ & \\
Sebelum & $110,9 \pm 22,1$ & $0,024^{\mathrm{A}}$ & $103,8 \pm 43,1$ & $0,815^{\mathrm{A}}$ \\
1 bulan & $114,5 \pm 21,2$ & & $105,9 \pm 37,8$ & \\
2 bulan & & & & \\
\hline Tingkat Kecukupan & $111,8 \pm 37,8$ & & & \\
Protein & $132,6 \pm 22.34$ & $0,129^{\mathrm{A}}$ & $110,6 \pm 46,6 \pm 59,2$ & $0,841^{\mathrm{A}}$ \\
Sebelum & $133,4 \pm 34,8$ & & $119,9 \pm 58,2$ & \\
1 bulan & & & & \\
2 bulan & & &
\end{tabular}


Perubahan Tingkat Kecukupan Energi dan Protein Sebelum dan Setelah Intervensi Antara Kelompok Perlakuan dan Kontrol

Tabel 5 menunjukkan tidak ada perbedaan peningkatan tingkat kecukupan energi dan protein sesudah intervensi pada kelompok perlakuan dan kontrol $(p>0,05)$. Perbedaan peningkatan tingkat kecukupan energi dan protein sebelum dan setelah intervensi pada kedua kelompok dapat dilihat pada Tabel 5.

Tabel 5. Perbedaan Tingkat Kecukupan Energi dan Protein Setelah Intervensi Antara Kelompok Perlakuan dan Kontrol

\begin{tabular}{cccc}
\hline Variabel & Perlakuan $(\mathrm{n}=20)$ & Kontrol $(\mathrm{n}=21)$ & \multirow{2}{*}{$p$} \\
\cline { 2 - 3 } & Mean $\pm \mathrm{SD}$ & Mean $\pm \mathrm{SD}$ & \\
\hline$\Delta$ Peningkatan TKE & $9,5 \pm 1,9$ & $-0,6 \pm 3,3$ & $0,090^{\mathrm{w}}$ \\
Sebelum - 1 bulan & $3,5 \pm 7,8$ & $2,2 \pm 2,7$ & $0,825^{\mathrm{i}}$ \\
1 - 2 bulan & $12,8 \pm 1,9$ & $6,5 \pm 2,7$ & $0,144^{\mathrm{w}}$ \\
\hline sebelum - 2 bulan & & & \\
\hline Peningkatan TKP & $20,8 \pm 2,7$ & $7,8 \pm 5,5$ & $0,345^{\mathrm{i}}$ \\
Sebelum - 1 bulan & $0,9 \pm 2,2$ & $1,5 \pm 1,4$ & $0,946^{\mathrm{i}}$ \\
1 - 2 bulan & $21,6 \pm 2,6$ & $9,3 \pm 4,4$ & $0,287^{\mathrm{i}}$ \\
\hline sebelum - 2 bulan & &
\end{tabular}

Keterangan: $p^{i}=$ independent $t$-test,${ }^{w}=$ Mann-Whitney

Tidak ada korelasi antara tingkat kecukupan energi dan protein dengan skor $\mathrm{z}$ indeks dan $\mathrm{BB} / \mathrm{TB} \quad(p=0,416 ; 0,138)$ dalam 2 bulan intervensi. Dapat dinyatakan tingkat kecukupan energi dan protein bukan merupakan variabel pengganggu dalam penelitian ini. $\mathrm{BB} / \mathrm{U} \quad(p=0,565 ; 0,236), \quad \mathrm{TB} / \mathrm{U} \quad(p=0,835 ; 0,397)$

\begin{abstract}
Kejadian Diare dan ISPA pada Kelompok Perlakuan dan Kontrol

Data morbiditas pada penelitian ini adalah ISPA (infeksi saluran pernafasan atas) serta diare. Kejadian diare hanya dialami oleh 2 orang anak pada kelompok perlakuan dan kontrol selama 1 hari, sehingga data diare tidak dianalisis. Data morbiditas ISPA dihitung berdasarkan persentase jumlah hari sakit dibandingkan jumlah hari pengamatan (60hari).
\end{abstract}

Tabel 6. Kejadian ISPA

\begin{tabular}{cccc}
\hline \multirow{2}{*}{ Variabel } & Perlakuan $(\mathrm{n}=20)$ & Kontrol $(\mathrm{n}=21)$ & \multirow{2}{*}{$p$} \\
\cline { 2 - 3 } & Mean \pm SD & Mean \pm SD & \\
\hline Persentase hari sakit ISPA & $10,0 \pm 6,8$ & $10,4 \pm 6,4$ & $0,837^{\mathrm{i}}$ \\
\hline
\end{tabular}

Keterangan: $i=$ independent $t$-test

Tabel 6 menunjukkan bahwa tidak ada perbedaan kejadian ISPA antara kedua kelompok sehingga variabel ISPA bukan merupakan variabel pengganggu dalam penelitian ini.

\section{PEMBAHASAN}

Rerata TB kelompok perlakuan mengalami peningkatan lebih besar dibandingkan kelompok kontrol dari 76,2 $\mathrm{cm}$ menjadi 78,6 dalam 1 bulan dan 79,3 dalam 2 bulan perlakuan, sedangkan kelompok kontrol mengalami peningkatan dari $76,5 \mathrm{~cm}$ menjadi 77,9 $\mathrm{cm}$ dalam 1 bulan dan 78,4 dalam 2 bulan. Hal ini sejalan dengan peningkatan rerata skor $\mathrm{z}$ indeks $\mathrm{TB} / \mathrm{U}$ pada kelompok perlakuan dibandingkan kelompok kontrol. Rerata skor $\mathrm{z}$ indeks $\mathrm{TB} / \mathrm{U}$ meningkat dari $-3,1 \pm 0,7$ menjadi $-2,5 \pm 0,6 \quad(p=0,03)$ untuk kelompok perlakuan sedangkan $-3,0 \pm 0,8$ menjadi $-2,9 \pm 0,9$ untuk kelompok kontrol selama 2 bulan perlakuan. Skor $\mathrm{z}$ indeks $\mathrm{BB} / \mathrm{U}$ meningkat dari $-1,9 \pm 0,9$ menjadi $-1,8 \pm 0,8$ pada kelompok perlakuan namun skor $\mathrm{z}$ indeks $\mathrm{BB} / \mathrm{U}$ dan $\mathrm{BB} / \mathrm{TB}$ tidak mengalami peningkatan yang signifikan. Perubahan skor $\mathrm{z}$ indeks $\mathrm{BB} / \mathrm{TB}$ yang tidak signifikan dapat disebabkan karena peningkatan BB dan TB namun tidak sesuai dengan umur. Berdasarkan WHO Anthro (2005) anak usia 12-36 bulan memiliki berat badan rata-rata $12 \mathrm{~kg}$ dan tinggi rata-rata $85-90 \mathrm{~cm}$. Rerata berat badan dan 
tinggi badan subjek dalam penelitian ini masih dibawah standar WHO.

Suplementasi micronutrient sprinkle mempunyai efek langsung terhadap peningkatan skor $\mathrm{z}$ indeks $\mathrm{TB} / \mathrm{U}$ pada kelompok perlakuan. Hal ini dibuktikan dengan data skor $z$ indeks $T B / U$ selama 2 bulan intervensi dengan tingkat kecukupan energi dan protein tidak ada korelasi yang signifikan $(p>0,05)$. Hal ini juga sesuai dengan penelitian Chhagan et all (2010) yang meneliti bahwa suplementasi dengan berbagai mikronutrien pada anak usia 6-24 bulan selama 6 bulan dengan kategori stunting mengalami peningkatan skor $\mathrm{z}$ indeks $\mathrm{TB} / \mathrm{U}$ sebanyak 0,7 pada anak yang berusia lebih dari 18 bulan namun untuk perubahan skor $\mathrm{z}$ indeks $\mathrm{BB} / \mathrm{U}$ tidak mengalami perubahan yang signifikan. ${ }^{14}$

Hasil penelitian ini menunjukkan peningkatan rerata berat badan walaupun tidak terdapat perbedaan yang signifikan dari $9,3 \mathrm{~kg}$ menjadi 9,8 kg dengan dosis 2 hari sekali selama 2 bulan (60 hari) intervensi pada kelompok perlakuan, lebih tinggi daripada kelompok kontrol dari 9,3 kg menjadi 9,4 kg. Peningkatan berat badan ini dapat disebabkan karena terjadinya peningkatan nafsu makan sebagai efek dari pemberian micronutrient sprinkle. Salah satu zat gizi mikro yang terkandung dalam micronutrient sprinkle yaitu seng. Asupan seng yang diberikan melalui taburia pada kelompok perlakuan meningkat sehingga terjadi penurunan absorbsi dan peningkatan ekskresi melalui usus, membuat anak menjadi lebih cepat lapar sehingga asupan makan anak juga dapat meningkat. ${ }^{25}$ Berat badan merupakan indikator energi yang adekuat/inadekuat. Hal ini sesuai dengan hasil penelitian bahwa terdapat peningkatan yang signifikan terhadap tingkat kecukupan energi pada kelompok perlakuan dari $96,1 \%$ menjadi $114,5 \%$ dalam 2 bulan perlakuan.

Komposisi taburia sudah disesuaikan dengan rekomendasi perhari dari WHO. Micronutrient sprinkle mengandung mikronutrien yang terdiri dari 16 vitamin dan mineral yang mendukung proses pertumbuhan balita. Dalam berbagai penelitian, kejadian defisiensi zat gizi yang terjadi pada balita di negara berkembang dengan satu jenis suplementasi mikronutrien mempunyai efek terbatas terhadap pertumbuhan. Padahal di berbagai penelitian defisiensi zinc, vitamin A, besi dan mikronutrien lain sering ditemukan bersamaan. Penelitian terbaru menemukan bahwa mineral berperan terhadap hampir semua enzim dan sisi aktif enzim sebagai kofaktor sedangkan vitamin sebagai koenzim. Micronutrient sprinkle mengandung berbagai macam vitamin dan mineral yang mempengaruhi metabolisme antara lain vitamin A yang berpengaruh terhadap sintesis protein dan pertumbuhan sel sedangkan vitamin B1, B2, B3, B6, B12 dimanfaatkan dalam metabolisme lemak, protein dan karbohidrat. ${ }^{10,16}$

Seng mempunyai pengaruh yang signifikan terhadap pertumbuhan anak apabila indikator status antropometrinya di bawah ratarata. ${ }^{11}$ Seng mempengaruhi hormon pertumbuhan dan sistem insulin-like growth factor yang berpengaruh terhadap metabolisme tulang. ${ }^{17}$ Besi sangat esensial untuk mengikat dan transpor oksigen, sangat baik untuk regulasi dan diferensiasi sel pertumbuhan. Intake yodium yang adekuat mempengaruhi perkembangan intelektual serta pertumbuhan fisik. ${ }^{20}$ Vitamin D berperan dalam tumbuh kembang tulang. Status vitamin D yang adekuat diperlukan untuk absorbsi kalsium dan mengatur kadar kalsium dan fosfat yang dibutuhkan dalam darah untuk mineralisasi tulang. ${ }^{23}$ Vitamin $\mathrm{K}$ meningkatkan fungsi dari vitamin $\mathrm{D}$ yang penting untuk kesehatan tulang. ${ }^{24}$

Berdasarkan observasi, sebelum intervensi terdapat subjek yang semula hanya mau mengonsumsi ASI, namun setelah 2 bulan perlakuan subjek mulai mengonsumsi nasi. Berdasarkan wawancara dengan orang tua subjek pada kelompok perlakuan, sejak mengikuti intervensi micronutrient sprinkle, subjek menjadi lebih cepat lapar sehingga mempengaruhi nafsu makan yang semakin meningkat pula serta subjek menjadi anak yang lebih aktif. Berdasarkan hasil recall, asupan energi dan protein pada kelompok perlakuan dan kontrol sebagian besar berasal dari jajanan sehingga sumber makanan yang mengandung mikronutrien sangat kurang. Hal ini dibuktikan dengan rerata asupan besi pada kelompok perlakuan 3,6 mg dan kelompok kontrol 3,1 mg serta asupan seng kelompok perlakuan 2,5 mg dan kelompok kontrol 2,4 mg. Rerata asupan besi dan seng pada kedua kelompok masih dibawah standar AKG yaitu $8 \mathrm{mg}$ besi dan $8,2 \mathrm{mg}$ seng. Meskipun asupan makanannya adekuat namun bioavailabilitas zat gizi seperti besi, kalsium, seng, vitamin A, dll kurang. Suplementasi dengan micronutrient sprinkle sangat tepat karena dapat memberikan dampak terhadap status antropometri terutama skor $\mathrm{z}$ indeks $\mathrm{TB} / \mathrm{U}$ dan peningkatan nafsu makan.

Hal ini sesuai dengan penelitian Kounnavong S, et all (2011) yang meneliti bahwa 
suplementasi mikronutrien pada anak usia 6-53 bulan selama 24 minggu dengan dosis 2 kali seminggu atau 1 kali perhari mempunyai efek yang positif terhadap pertambahan tinggi badan. Tidak maksimalnya efek suplementasi dikarenakan kualitas asupan makanannya kurang dibanding dengan kuantitasnya. ${ }^{22}$ Faktor makanan yang kurang memenuhi kebutuhan zat gizi, mungkin anak cukup kenyang, tetapi makanannya tidak cukup kandungan gizinya sehingga anak tersebut mengalami gangguan pertumbuhan dan kekurangan zat gizi tertentu.

Edukasi gizi selama 2 bulan yang diadakan dalam penelitian ini bertujuan untuk menyamakan persepsi orang tua subjek terhadap gizi seimbang. Hal ini memberikan dampak, dibuktikan dengan meningkatnya tingkat kecukupan energi dan protein selama 2 bulan penelitian pada kelompok perlakuan dan kontrol, walaupun pada kelompok kontrol tidak terjadi peningkatan yang signifikan. Efektivitas intervensi micronutrient sprinkle dalam memperbaiki status gizi dapat dirasakan setelah satu bulan intervensi. Hal ini dapat ditunjukkan dengan adanya perubahan rerata $\mathrm{BB}, \mathrm{TB}$ dan skor $\mathrm{Z}$ indeks $\mathrm{TB} / \mathrm{U}$ mengalami perubahan yang signifikan setelah 1 bulan intervensi (Tabel 3).

\section{SIMPULAN}

Suplementasi micronutrient sprinkle selama 2 bulan meningkatkan skor $\mathrm{z}$ indeks TB/U pada anak stunting usia 12-36 bulan tetapi tidak meningkatkan skor $\mathrm{z}$ indeks $\mathrm{BB} / \mathrm{U}$ dan $\mathrm{BB} / \mathrm{TB}$ pada anak stunting usia 12-36 bulan.

\section{SARAN}

Anjuran pemberian makanan dengan gizi seimbang disertai dengan pemberian micronutrient sprinkle dapat dilakukan pada anak stunting untuk membantu peningkatan pertumbuhan.

\section{DAFTAR PUSTAKA}

1. Sedgh G, M. Guillermo H, Penelope N, Alawia el A, Wafaie WF. Dietary vitamin A intake and nondietary factors are associated with reversal of stunting in children. American Society for Nutritional Science . 2000 Jun 14.

2. Lapriore C, Tamina G, Andre B, Fransesco B. Spread fortified with vitamins and minerals induces catch-up growth and eradicates severe anemia in stunted refugee children aged 3-6 y. Am J Clin Nutr. 2004;80:973-81.

3. RISKESDAS (Riset Kesehatan Dasar) 2010. Badan Penelitian dan Pengembangan Kesehatan. Republik Indonesia; 2010.
4. Taguri AE, Ibrahim B, Salah MM, Abdel MA, Oliver G, Pilar G, Serge H. Risk factors for stunting among under-fives in Libya. Public Health Nutrition. 2008 Sept 15: 12(8). 1411-1149.

5. Mandal G C, Kaushik B, Samiran B, Sanjib G. Undernutrition among Integrated Child Development Services (ICDS) Scheme Children aged 2-6 years of Arambag, Hooghly District, WestBengal, India: A serious public health problem. IJPH. 2008.

6. Astari LD, Amini N, Cesilia MD. Hubungan konsumsi ASI dan MP-ASI serta kejadian stunting anak usia 6-12 bulan di Kabupaten Bogor. Media Gizi dan Keluarga. 2006 Jul.

7. Helmi AF, A. Razak T, Ridwan M. Thaha. Kepatuhan ibu dalam pemberian TABURIA pada anak umur 6-24 Bulan di Kabupaten Pangkep Tahun 2011.

8. Zlotkin SH, Claudia S, Anna C, et al. Micronutrient sprinkles to control childhood anemia. PloS Medicine. 2005 Jan. Available from http:// www.plosmedicine.org

9. Golden $\mathrm{M} \mathrm{H}$. Proposed recommended nutrient densities for moderately malnourished children. Food and Nutrition Bulletin, vol 30, no 3. 2009.

10. Rauf S, Faramitha. Pengaruh pemberian taburia terhadap perubahan status gizi anak gizi kurang umur 12-24 bulan di Kecamatan Pangkep tahun 2010. Makassar: Gizi Poltekkes Kemenkes. Vol XIII, Edisi 1, 2012.

11. Bui DT, Werner S, Drupadi D, Rainer G, Nelly DL, Ha HK. Effect of daily and weekly micronutrient supplementation on micronutrient deficiencies and growth in young Vietnamese children. Am J Clin Nutr. 1999; 69:80-6

12. Malina R. Normal weight gain in growing children. Healthy Weight Journal. 1999 June. Vol 13.

13. WHO: Global Database on Child Growth and Malnutrition.

14. Chhagan MK, Jan VB, Kany AL, Nontobeko M, Andrew T, Michael LB. Effect on longitudinal growth and anemia of zinc or multiple micronutrients added to vitamin $\mathrm{A}$ : a randomized controlled trial in children aged 6-24 months. BMC Public Health. 2010,10:145.

15. Lipoeto NI, Novi M, Andani EP. Malnutrisi dan asupan kalori pada pasien rawat inap di rumah sakit. Padang: Fakultas Kedokteran Universitas Andalas. 2006. Vol 56 no 11.

16. Shenkin A, The key role of micronutrients. Elsevier Clinical Nutrition Journal. 2006.

17. Eckhardt CL. Miicronutrient malnutrition, obesity and chronic disease in countries undergoing the nutrition transition: potential links and program/policy implications. International Food Policy Research Institute. 2006 Nov.

18. Erna KW. Hubungan episode infeksi saluran pernapasan akut (ISPA) dengan pertumbuhan bayi 
umur 3 sampai 6 bulan. Semarang: Magister Gizi Masyarakat Universitas Diponegoro. 2005 Des.

19. Bhandari N, Rajiv B, Sunita T. Effect of micronutrient supplementation on linear growth of children. British Journal of Nutrition. 2001; p. 131-137

20. Caulfield LE, Stephanie AR, Juan AR, Philip M, Robert B. Stunting, wasting and micronutrient disorders. ch. 28.

21. Measuring change in nutritional status: Guidelines for assessing the nutritional impact of supplementary feeding programmes for vulnerable groups. Geneva: WHO. 1983.

22. Kounnavong S, et all. Effect of daily versus weekly home fortification with multiple micronutrient powder on haemoglobin concentration of young children in a rural area, Lao People's Democratic Republic: a randomised trial. Nutrition Journal. 2011,10:129.

23. European food safety authority. Vitamin D and bone growth. The EFSA Journal. 2008;827, 1-10.

24. Bonjour JP, Leon G, Cristina P, Martin JS, Connie MW. Mineral and vitamins in bone helath: the potential value of dietary enhancement. British Journal of Nutrition. 2009, 101, 1581-1596.

25. Sjarif DR, Endang DL, Maria M, Sri SN. Nutrisi pediatrik dan penyakit metabolik. Jakarta: IDAI. 2011.

26. Castillo L. Macronutrient requirement for growth: protein and amino acids. London: Nutrition in Pediatrics. Ed 3.2003:73-85. 